\title{
Flammability behaviour of wood and a review of the methods for its reduction
}

\author{
Laura Anne Lowden* and Terence Richard Hull
}

\begin{abstract}
Wood is one of the most sustainable, aesthetically pleasing and environmentally benign materials. Not only is wood often an integral part of structures, it is also the main source of furnishings found in homes, schools, and offices around the world. The often inevitable hazards of fire make wood a very desirable material for further investigation. As well as ignition resistance and a low heat release rate, timber products have long been required to resist burnthrough and maintain structural integrity whilst continuing to provide protection when exposed to fire or heat. Various industry standard tests are thus required to ensure adequate protection from fire is provided.

When heated, wood undergoes thermal degradation and combustion to produce gases, vapours, tars and char. In order to understand and alter the fire behaviour of wood, it is necessary to know in as much detail as possible about its processes of decomposition. Various thermal analysis and flammability assessment techniques are utilised for this purpose, including thermogravimetric analysis, cone calorimetry and the single burning item test. The results of such tests are often highly dependent on various parameters including changes to the gas composition, temperature, heating rate, and sample shape size.

Potential approaches for fire retarding timber are reviewed, identifying two main approaches: char formation and isolating layers. Other potential approaches are recognised, including the use of inorganic minerals, such as sericrite, and metal foils in combination with intumescent products. Formulations containing silicon, nitrogen and phosphorus have been reported, and efforts to retain silicon in the wood have been successful using micro-layers of silicon dioxide. Nano-scale fire retardants, such as nanocomposite coatings, are considered to provide a new generation of fire retardants, and may have potential for wood. Expandable graphite is identified for use in polymers and has potential for wood provided coating applications are preferred.
\end{abstract}

Keywords: Wood; Timber; Fire; Fire retardant; Pyrolysis; Combustion

\section{Introduction}

Wood is one of the most sustainable, aesthetically pleasing and environmentally benign materials. The demand to use wood and wood-based products for applications in both residential and non-residential building construction has been increasing over recent years. However, due to the inherent flammability of such products, they often contribute to unwanted fires, resulting in numerous injuries and fatalities. The use of wood is, therefore, limited by various safety requirements and regulations pertaining to its flammability and spread of fire characteristics.

In order to improve the reaction to fire performance, timber products are commonly treated with fire retar-

\footnotetext{
* Correspondence: lalowden@uclan.ac.uk

University of Central Lancashire, Preston, UK
}

dants. At present, the level of development of such products with improved fire performance does not match the increasing use. Some of the fire retardant timber treatments are almost two millennia old, where alum and vinegar were first used. Little improvement has been observed since, with treatments exploiting the synergism between boron, phosphorus and nitrogen to promote char formation still prominent. The growing awareness of environmental issues and consumer safety of fire retardant products, however, means that the traditional use of boron and formaldehyde is likely to decline.

In addition to the environmental credentials of a timber treatment, its ancillary properties, and the effect it has on that of timber, must be assessed. The hydrophilic character of wood is one of which. It gives rise to a variable equilibrium moisture content, which can result in 
poor dimensional stability and low resistance to microbiological decay. Fire retardants can be hygroscopic and thus attract water into the wood structure. Other properties include the corrosion, glueability and paintability of the fire retardant treated timber, all of which should be considered carefully depending on the end use of the product.

Strong development in new technologies and products in the last decades has been observed for the fire retardant treatment of plastics and fabrics, including nanocomposites (Laoutid et al. 2009) and layer by layer applications (Alongi et al. 2013a). The transference of these technologies to the commercial world is unknown. Nevertheless, close collaboration between the scientific disciplines is required in order to ensure the continued growth of such developments, and to ensure the development of fire retardant timber treatments.

\section{Wood structure and properties}

Wood is a renewable, sustainable and easily workable material that has been used in the building industry for thousands of years. Its use remains widespread, ranging from structural frames to floors, paneling, doors, interior and exterior woodwork, and furniture. (Rowell 1984) has provided an in-depth description of the chemistry and structure of wood. Its three main components (cellulose, hemicellulose and lignin) are discussed thoroughly and an understanding of wood as a composite is provided. A wider overview of wood structure from an engineering and architectural perspective is provided by (Bergman et al. 2010).

Wood is composed of elongated cells, most of which are orientated in the longitudinal direction of the stem. These cells are connected to one another through openings, known as pits, and vary in their shape according to their function. Functions exhibited by the cells are to provide mechanical strength to the tree, perform the function of liquid transport and storage of reserve food supplies.
Cellulose, hemicellulose and lignin are the three polymeric materials that constitute the wood cells. Cellulose is a polymer with alternating repeat units of glucose (Figure 1). Cellulose derived from wood pulp has an average of 3000 repeat units (Bergman et al. 2010). The large number of hydroxyl groups on the sugar molecule, which leaves the polymer as water molecules during decomposition, result in char formation. In the wood structure, cellulose forms the cell walls, and provides the tensile strength of the wood matrix. Hemicelluloses grow around the cellulose fibres and are a group of nonstructural, low molecular weight, mostly heterogeneous polysaccharides. Lignin is an aromatic polymer, which allows trees to grow upright by imparting rigidity to the wood: it cements the cells together, thus accounting for the compressive and shear strengths of wood.

Although wood is essentially polymeric, its structure varies greatly between, and within, species. At the simplest level, wood used by the construction industry is typically separated into two categories: hardwoods and softwoods. The terms hardwood and softwood do not reflect the physical properties, as might be imagined. Some hardwoods are relatively soft, and some softwoods are relatively hard. Hardwoods are broad-leaved species and softwoods are coniferous species. In softwoods, the main cell type is the tracheid, which constitutes over $90 \%$ of the volume of softwoods. In hardwoods, $50 \%$ of the volume is made up of fibres and fibre tracheids, which are considerably shorter and thicker-walled than softwood tracheids (Rowell 1984). Hardwood fibres typically also have higher hemicellulose content than softwood tracheids. High hemicellulose contents give rise to weak fibres.

In both hardwoods and softwoods, the wood in the trunk of the tree is divided into two zones, heartwood and sapwood. Both of these groups serve an important function, distinct from the other. Sapwood is the band of lighter coloured wood located within the outer
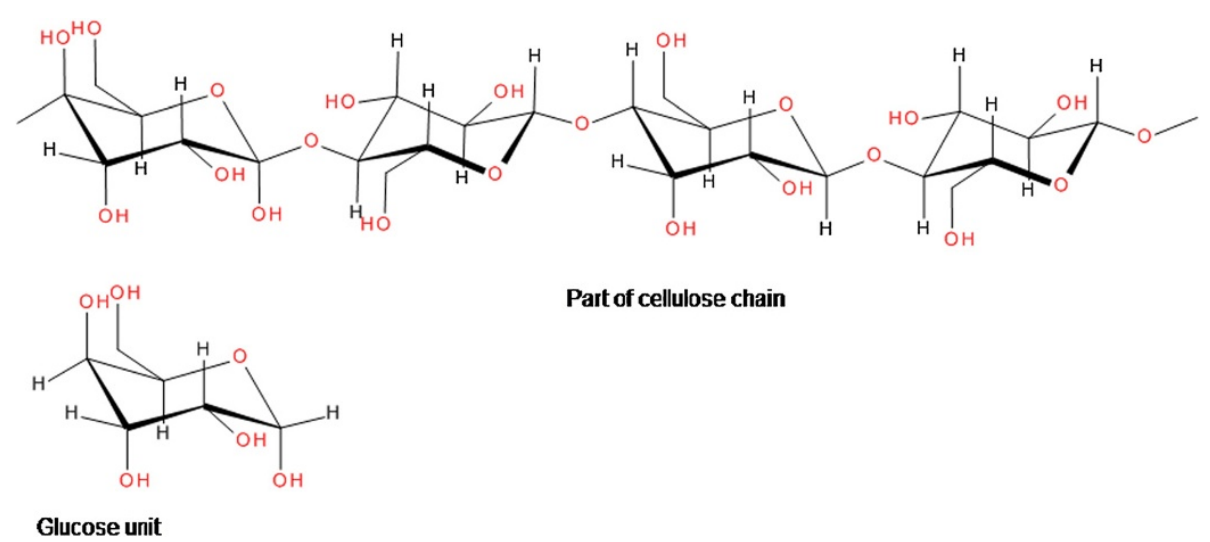

Part of cellulose chain 
portion of the tree. It carries water, minerals and plant sugars between the roots and leaves. Heartwood is the darker coloured wood, surrounded by sapwood, which is made up of dead cells that no longer serve any purpose except to support the tree. Many hardwoods typically have larger heartwood zones, which has a positive impact on the durability properties of the wood (Wiedenhoeft and Miller 2005). Most softwood is available far cheaper than any hardwood due to its increased growth and obtainability. As such, softwood is most commonly used by the construction industry (McDonald and Kretschmann 1999).

\section{Wood combustion and fire retardancy Pyrolysis and combustion}

When wood is progressively heated at raised temperatures, changes begin to occur in its structure, accelerated by further increase in temperature. The three polymeric components in the wood begin to thermally decompose to a mixture of volatile gases, tar (levoglucosan) and carbonaceous char. The decomposition is often regarded as the superposition of the individual constituent's decomposition mechanisms: hemicellulose decomposes first $\left[180-350^{\circ} \mathrm{C}\right]$ followed by cellulose $\left[275-350^{\circ} \mathrm{C}\right]$, and lignin $\left[250-500^{\circ} \mathrm{C}\right]$ (Kim et al. 2006). The thermal stability of lignin is considered to be due to its heavily cross-linked structure and high molecular weight (Yang et al. 2006).

Cross-linking reactions dehydrate cellulose and the repolymerized levoglucosan begin to yield aromatic structures, becoming graphitic carbon structures at around $500^{\circ} \mathrm{C}$. This decomposition process is termed pyrolysis. Wood pyrolysis has been the subject of extensive research over the last years (Bland 1991; Reszka 2008; Yang et al. 2003). Such studies have shown that whilst the charred surface of wood can have temperatures of $800^{\circ} \mathrm{C}$, the main pyrolysis of wood begins at temperatures above $225^{\circ} \mathrm{C}$ and ends below $500^{\circ} \mathrm{C}$.

When an appropriate volatile fuel-air concentration has been reached, oxidation of the pyrolysis gases leads to flaming combustion (Babrauskas 2002; Hirata et al. 1991; McNaughton 1945). In contrast, oxidation of the remaining char produces glowing or smouldering combustion. The pyrolysis and combustion of wood has been reviewed (Browne 1958; Friquin 2010; Jonsson and Pettersson 1958) and studied extensively (Carling 1990; Dietenberger 2002; Mikkola 1990; Parker 1992; White and Dietenberger 2001); the key discoveries are summarised in Table 1.

\section{Formation of char}

Two forms of gaseous products are produced by wood pyrolysis: those that escape readily from the solid residue and those that don't. For those that do, nearly all of the compounds that split off from cellulose and lignin in the earlier stages of pyrolysis are richer in hydrogen, in oxygen, or in both, than the original polymeric chains. The non-volatile residue, therefore, becomes enriched in carbon. The carbon-to-carbon bonds in the graphitic carbon structures formed are unbreakable by pyrolysis alone to temperatures beyond $3000^{\circ} \mathrm{C}$ (Browne 1958). For those complex gaseous products that do not readily escape from the solid residue, exothermic pyrolysis continues to leave a more highly carbonaceous residue, and form a secondary char.

Char formation has a significant effect on decomposition. Clearly, if material is left in the solid phase as char, the decomposition of the underlying wood is slowed. Although the char does not impart strength to the remaining material, it acts as an increasing thermal resistance between the underlying wood and the pyrolysis front. This results in a decrease in heat release rate and acts as a mass transport barrier for volatiles released from the fuel and oxygen from the air.

The structure of the char varies widely depending on wood species, fire retardant treatment and heating rate, and its stability and integrity is influenced by many characteristics, including density, continuity, oxidationresistance, thermal insulation properties and permeability. Its production highly depends on the rate and length of heating: sharp increases in temperature yield less char than gradual increases, since char production is dependent on low-temperature dehydration reactions.

Table 1 Temperature ranges of wood pyrolysis and combustion

\begin{tabular}{ll}
\hline Temperature range & Decomposition processes \\
\hline$>100^{\circ} \mathrm{C}$ & The evaporation of chemically unbound water. \\
$160-200^{\circ} \mathrm{C}$ & $\begin{array}{l}\text { The three polymeric components of wood begin to decompose } \\
\left.\text { slowly. Gases formed at this stage are non-combustible (mainly } \mathrm{H}_{2} \mathrm{O}\right) .\end{array}$ \\
$200-225^{\circ} \mathrm{C}$ & Wood pyrolysis is still very slow, and most of the gases produced are non-Combustible. \\
$225-275^{\circ} \mathrm{C}$ & The main pyrolysis begins and flaming combustion will occur with the aid of a pilot flame. \\
$280-500^{\circ} \mathrm{C}$ & $\begin{array}{l}\text { Gases produced are now volatile (CO, methane etc.) and smoke particles are } \\
\text { visible. Char forms rapidly as the physical structure of wood breaks down. }\end{array}$ \\
$>500^{\circ} \mathrm{C}$ & Volatile production is complete. Char continues to smoulder and oxidise to form $\mathrm{CO}, \mathrm{CO}_{2}$ and $\mathrm{H}_{2} \mathrm{O}$. \\
\hline
\end{tabular}


The decomposition of lignin is known to make a significant contribution to the overall char yield (Browne 1958).

Whilst the addition of fire retardants often increases the char yield of wood, the charring rate typically remains unchanged. Typical charring rates of softwoods are of the order of $0.6 \mathrm{~mm} \mathrm{~min}{ }^{-1}$ using the standard test methods for determining fire resistance ratings for structural members and assemblies [ASTM E119 (2012) or ISO 834 (2012)]; however, they depend on important factors including density, thickness of the char layer, moisture content, oxygen concentration and external heat flux (Friquin 2010; Mikkola 1990).

\section{Smoke production and toxicity}

Less smoke is produced by wood than from many plastics. In well-ventilated conditions, wood can produce 25-100 $\mathrm{m}^{2} \mathrm{~kg}^{-1}$ of smoke, whereas plastic materials can release hundreds or thousands $\mathrm{m}^{2} \mathrm{~kg}^{-1}$ (Hakkarainen et al. 2005). Smoke production depends on the burning material and on factors including oxygen supply and type of combustion (e.g. flaming or glowing).

Smoke released during a fire poses severe risks to the fire safety of occupants in buildings: not only does it reduce visibility thus reducing the likelihood of escape from a burning building, its gases have irritating, and lethal, effects. Primary products of wood combustion are carbon monoxide, carbon dioxide and water (Karpovic et al. 2012; Wilkins and Murray 1980). However, hydrogen cyanide and hydrogen halides can be released if heteroelements such as nitrogen or halogens are present. Fire retardants containing such heteroelements or other inhibitors can increase the yield of smoke and its toxic components, but by slowing the rate of burning can also cause a reduction in smoke and toxic gas production rates. Commercial smoke suppressants can be added to fire retardants to reduce the quantity of smoke produced, examples include zinc borate, and molybdenum and tin compounds (Green 1996).

The toxicity of fire retardants plays an important role in health and safety legislation and any candidate fire retardant should be considered as a result of this. Halogenated, particularly bromine-containing, flame retardants are now widely recognised as being environmentally unfriendly due to their bioaccumulation in people and adverse health effects in children (Janssen 2005). In addition, boric acid has recently been under scrutiny, following its reclassification as toxic for reproduction category $1 \mathrm{~B}$ according to CLP Regulation (EC) No 1272/ 2008 (European Chemicals Agency 2008), and its inclusion as a candidate for authorisation as a Substance of Very High Concern (SVHC) under REACH (Registration, Evaluation, Authorisation and restriction of Chemicals) regulations (European Chemicals Agency, European
Chemicals Agency 2010a, European Chemicals Agency 2010b).

The SVHC list includes materials defined as carcinogenic, mutagenic or toxic to reproduction, persistent, bioaccumulative and toxic, and/or identified from scientific evidence as causing probable serious effects to human health or the environment. Any user of materials on the SVHC list is obliged by law to inform their customers of the presence of these chemicals in products. This is likely to reduce the use of boric acid. The borate industry refute the inclusion European Borates Association (2010), and a proposal has been submitted by Poland to the European Chemicals Agency for a reduction in reproduction toxicity classification to category 2 according to CLP Regulation (EC) No 1272/2008 (European Chemicals Agency 2013). Given the contentiousness of its use, and the numerous studies available reporting its harmfulness (Agency for Toxic Substances and Disease Registry 2010), boron as a fire retardant for timber treatment has been excluded from this review.

\section{Techniques for studying fire retardant treated timber}

There are various fire test methods used not only to evaluate the fire retardant performance of wood materials, but for research and development purposes. Micro- and bench-scale test methods are frequently used to investigate the fire behaviour of formulations of small sample sizes of timber treated with fire retardants, whilst large-scale test methods are used to test building materials and provide fire safety classifications for end-use. Irrespective of the angle of interest, there are several aspects of evaluation of reaction to fire performance: ignitability, flame spread, heat release, smoke generation, and fire effluent toxicity.

There are two common approaches for investigating the suitability of a given fire retardant on a small scale: thermal analysis and flammability assessment. The most commonly used methods for each are briefly described in the following sections and include thermogravimetric analysis, differential thermal analysis, cone calorimetry, lateral ignition and flame spread test (LIFT) and large scale calorimetry, such as the single burning item (SBI) test, used for regulatory classification. Other test methods are used to quantify smoke development and toxicity, e.g. Steady-state tube furnace (BS 7990 2003/ ISO TS 19,700) and NBS smoke density chamber (ISO 5659-2 2012).

\section{Thermal analysis}

In order to understand, and alter, the behaviour of wood in a fire, it is necessary to know in as much detail as possible about its process of decomposition. Such processes are often highly dependent on various parameters 
including changes to the gas composition (air, nitrogen, air/nitrogen, oxygen), temperature, heating rate, sample shape and sample size. The sensitivity to these parameters can help the analyst identify the decomposition processes occurring, and provide them with significant clues to interpret the fire behaviour.

\section{Thermogravimetric analysis}

The most common method used to investigate thermal decomposition is thermogravimetric analysis (TGA). TGA is a technique that provides quantitative decomposition information on a polymeric material and can be used to study degradation kinetics and char formation (Crompton 1989).

The sample (in milligram quantities) is subjected to a controlled temperature regime (typically consisting of a constant heating rate) whilst the weight of the sample is monitored throughout the decomposition. This provides a measurement of weight loss as a function of temperature. As the material is heated, it can either lose weight through drying or liberation of gases or volatiles, or it can gain weight through reaction with the test atmosphere. Since the concentration of oxygen under a flame is close to $0 \%$ (Schartel and Hull 2007), the mass loss in an inert atmosphere, such as nitrogen, is more representative of the production of fuel after ignition has occurred. The thermal stability of the wood can be evaluated from the data produced.

\section{Differential thermal analysis}

In differential thermal analysis (DTA), a sample and an inert reference sample with approximately the same heat capacity are subjected to the same temperature programme. If the decomposition process of the sample is endothermic, such as anaerobic pyrolysis or gasification, the temperature of the sample will trail behind the reference material. If the process is exothermic, such as char oxidation, then the temperature of the sample will exceed that of the reference. The differential temperature is then plotted either against time or temperature. Differential temperatures can also be seen in two inert samples that respond differently when heated.

Differential thermogravimetry (DTG) uses the same measurement as TGA, the output results are presented as the differential of mass loss over time to give the mass loss rate versus temperature. DTG curves are useful for mechanistic studies, where a good indication as to when the various stages of decomposition occur and the associated order are provided. This is useful for the determination of the effectiveness of mixtures, e.g. fire retardant additives in a wood/plastic composite, and particularly useful to highlight the number of decomposition reactions occurring and the temperatures at which the peak rates of pyrolysis occur.

\section{Flammability assessment}

Flammability is a catch-all term to describe the reaction to fire characteristics of a material. It cannot be represented by a single value, as several parameters are involved (Quintiere 1997). Flammability assessment methods are fundamental in the screening and evaluation of fire retardant materials. The majority of fire tests in common use aim to determine some of the following fire properties of materials:

- Ease of ignition - how readily the material ignites;

- Rate of flame spread - how rapidly fire spreads across a surface;

- Rate of heat release - how much heat is released and how quickly;

- Ease of extinction - how easily the flame chemistry leads to extinction;

- Smoke/toxic gas evolution - evolution rate, amount, and the composition of smoke released during the various stages of a fire (Friedman et al. 2003).

Many authors ascertain that the single most important parameter for determining a material's fire hazard is its heat release rate (HRR) [Babrauskas and Peacock 1992; Lyon and Walters 2002]. There are many experimental studies and reviews available in the literature on the heat release and reaction to fire performance of wood (Tran 1992; White 2000).

\section{Cone calorimetry}

The cone calorimeter (ISO 5660-1 2002) is the most widely used bench-scale fire test method in use, providing a variety of quantifiable flammability parameters. It is employed as a means of predicting how a material will behave in a real fire scenario by providing the user with the HRR, mass loss rate (MLR), smoke production, fire spread and ignition properties. The method does have its limitations, however, in that the test conditions are only specific to a well-ventilated fire scenario, and it only assesses one-dimensional fire propagation into the substrate, taking no account of surface flame spread. This prevents the attribution of results to under-ventilated fires or post flashover fires (Carpenter and Janssens 2005).

Cone calorimetry assesses the heat contribution to the fire by the product. It measures the heat release based on the principle that the net heat of combustion is proportional to the mass of oxygen required for combustion and it has been established that approximately $13.1 \mathrm{~kJ}$ of heat are released per $g$ of oxygen consumed. Test specimens have an area of $100 \times 100 \mathrm{~mm}$ and a maximum thickness of $50 \mathrm{~mm}$. Test specimens are uniformly heated by a radiant heating source and ignited through the use of a spark igniter. The material is continuously weighed in order to determine mass loss as a parameter 
in its own right, and as a function of time and heat release. Measurements are deduced from the effluent oxygen concentration and exhaust gas flow rates. The thermal radiation can be set for any heat flux between 0 and $100 \mathrm{~kW} \mathrm{~m}^{-2}$.

A typical cone calorimeter output obtained at a heat

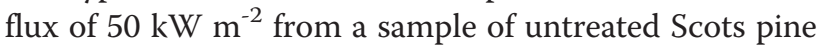
sapwood $\left(\right.$ density $=504 \mathrm{~kg} \mathrm{~m}^{-3}$ ) is provided in Figure 2 . The first peak in the curve occurs after an initial heating period, when the volatile pyrolysis gases are in sufficient supply to allow ignition by an external spark igniter to support ignition. The heat generated by combustion sustains the pyrolysis of wood, thus releasing more volatiles. The dip in the curve corresponds to the formation of the insulating char layer, where heat transfer is more difficult and the pyrolysis process is slowed (Marney et al. 2008). The second peak in the curve is believed to be caused by sample burn-through and char cracking, facilitating the escape of more volatiles (Spearpoint and Quintiere 2000). Following the exhaustion of volatiles, flaming combustion ends and the HRR returns to a steady baseline. In the absence of a protective char, the final peak in HRR in cone calorimetry is generally attributed to the lack of material below the pyrolysing fuel, which acts as a heat sink during steady burning. At the end of the test little heat transfer occurs to the glass wool supporting the sample.

\section{Microscale combustion calorimetry (pyrolysis combustion flow calorimetry)}

A relatively recent innovation in fire calorimetry has been the development of the microscale combustion calorimeter (MCC) [Figure 3]. This apparatus is utilised to determine the flammability characteristics of polymeric materials by use of combustion calorimetry on a microscale. The apparatus is used according to ASTM D 7309 (2011) and has been shown to give good repeatability (Yang and He 2012). The method was developed by the US Federal Aviation Administration (Lyon and Walters 2002; 2004).

MCC reproduces the solid-state and gas-phase processes of flaming combustion in a non-flaming test. Similar to the cone calorimeter, it can determine several of the parameters related to flammability including the peak heat release rate, heat of combustion, char yield and pyrolysis temperature, however unlike the cone calorimeter, the apparatus requires only milligram quantities $(\sim 5 \mathrm{mg})$ of sample. As the technique also utilises oxygen consumption calorimetry for determining HRR, combining the results of this method with those of the cone calorimeter can provide valuable heat release data at both the micro- and bench-scale. MCC is concerned with bulk burning, however, which means that it is of little sense to attempt the examination of fire retardants applied to the surface of the wood. In such cases, bench-scale methods, such as cone calorimetry, should be utilised.

No literature is found on the utilisation of MCC to study fire retardant treated timber. An unpublished typical MCC output of wood is shown in Figure 4. The onset of decomposition is indicated by a rise in HRR, which continues until the peak heat release rate is achieved. At this point, the pyrolysis temperature is also reached. Similar to the cone calorimeter, the area under the curve equates to the total heat release (THR) of the sample. Char yields are calculated by weighing the test specimen before and after the test run.

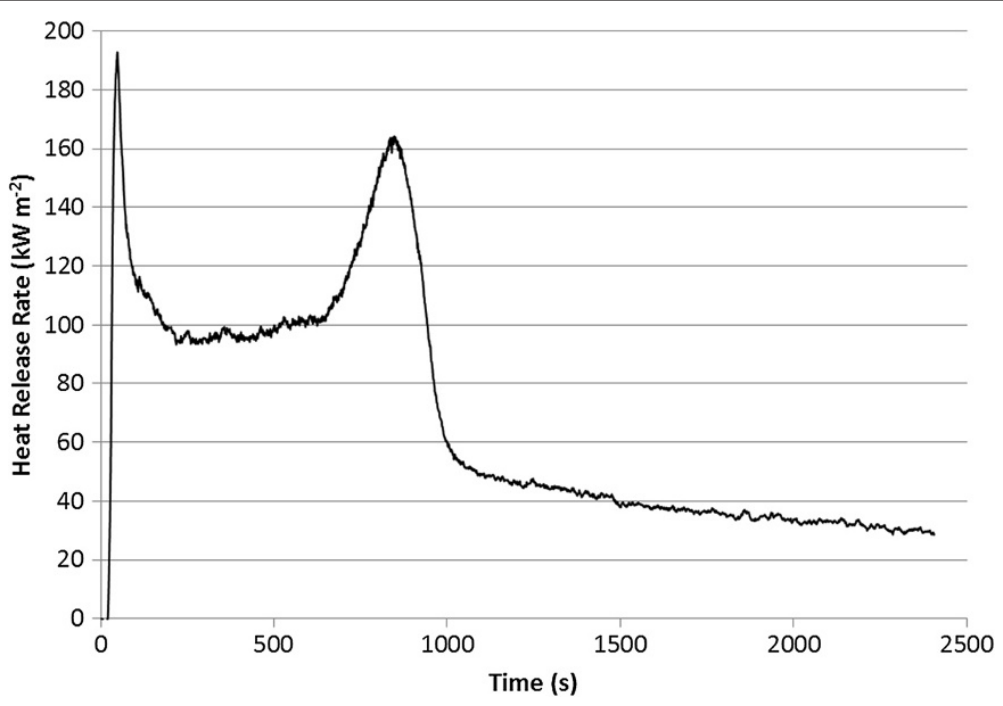

Figure 2 Typical heat release rate curve obtained at $50 \mathrm{~kW} \mathrm{~m}^{-2}$ by cone calorimetry for untreated Scots pine sapwood. 


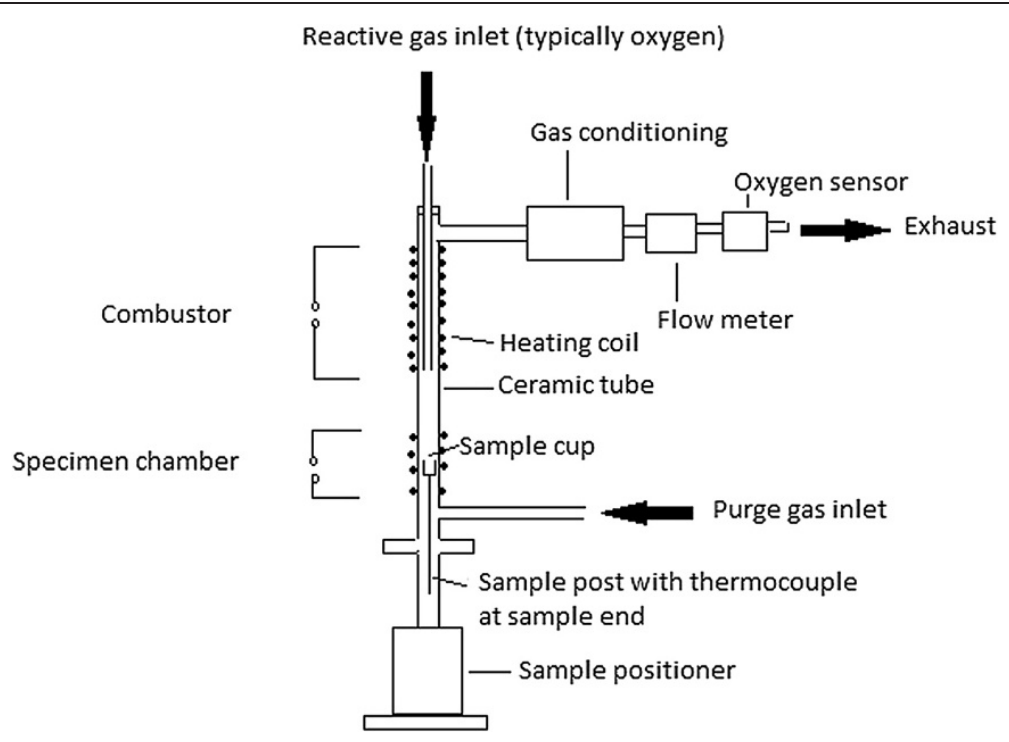

Figure 3 Schematic Diagram of Microscale Combustion Calorimetry (MCC).

Lateral ignition and spread of flame test (LIFT) apparatus (ISO 5658)

The LIFT apparatus (ISO 5658-22006) uses a radiative heat source, in the presence of a pilot flame, to measure the time to ignition and lateral spread of fire along the surface of a vertically orientated material of length $50 \mathrm{~cm}$ and width $15 \mathrm{~cm}$. The test is utilised for flat samples (that are positioned at an angle of $30^{\circ}$ in respect of the radiative heat source), which are primarily used as the exposed surfaces of walls. Subsequent to ignition, the horizontal progression of any fire along the sample is noted. The results are expressed in terms of fire spread distance/time, the fire front velocity versus heat flux, the critical heat flux at extinguishment and the average heat for sustained burning (Merryweather and Spearpoint 2008).

\section{Regulatory classification \\ Single burning item}

The single burning item (SBI) test is an intermediatescale test method (EN 13823) that is used to regulate construction products, excluding floorings. It is based on the fire threat from the burning of a single item, e.g. a wastebasket, located in the corner of two right-angled walls of the material to be tested. The test specimen walls are of sizes $1.0 \times 1.5 \mathrm{~m}$ and $0.5 \times 1.5 \mathrm{~m}$ and the single burning item ignition source is a triangle-shaped propane burner providing a maximum heat exposure of

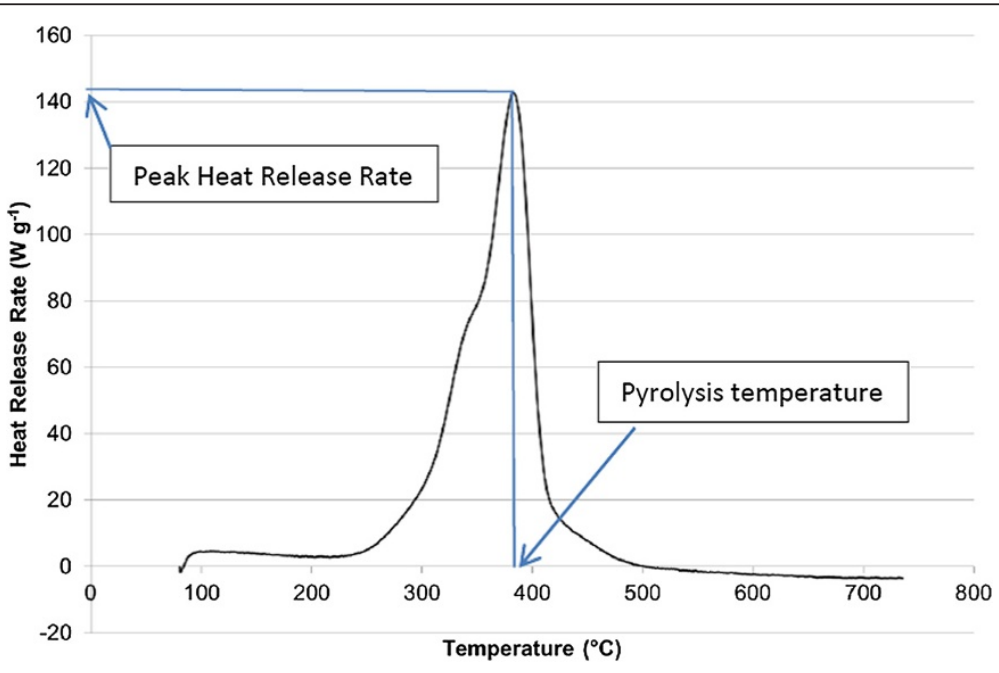

Figure 4 Typical heat release rate curve obtained by MCC for wood. 
approximately $40 \mathrm{~kW} \mathrm{~m} \mathrm{~m}^{-2}$ on an area of $300 \mathrm{~cm}^{2}$ (Hakkarainen et al. 2005). The end use application of a product should be as closely represented in the test as possible, e.g. mounting and fixing, substrate, presence of an air gap, exposed edges and joints.

Classification parameters contained within the SBI output are fire growth rate index (FIGRA), lateral flame spread (LFS), and THR. Additional classification is defined for smoke production in terms of smoke growth rate index (SMOGRA) and total smoke production (TSP). Each parameter is measured by means of sensors in the exhaust duct, recording temperature, light attenuation, $\mathrm{O}_{2}$ and $\mathrm{CO}_{2}$ mole fractions, and flow-induced pressure differences. These are used to allocate sheet materials into flammability Euroclass as part of the EU Construction Products Regulation 305/2011.

There are six Euroclasses ranging from Euroclass A (no contribution to fire) to Euroclass F (no performance determined). Only materials within classes B, C and D are subjected to the SBI test. Untreated timber products normally show a decrease in FIGRA values with increasing density. They normally meet the requirements of Euroclass D (acceptable contribution to fire: FIGRA < $750 \mathrm{~W} \mathrm{~s}^{-1}$ ) provided that the test specimen is thick and dense enough (see Classification Without Further Testing (CWFT) definitions for wood products). With fire retardant treatments, it is possible to reach class $\mathrm{C}$ (limited contribution to fire: FIGRA $<250 \mathrm{~W} \mathrm{~s}^{-1}$ ) or even class B (very limited contribution to fire: FIGRA < $120 \mathrm{~W} \mathrm{~s}^{-1}$ ), which gives more applications in construction compared to untreated timber.

Significant efforts by research professionals mean that it is now possible to predict a product's Euroclass from the cone calorimeter output (Messerschmidt et al. 1999; Hakkarainen and Kokkala 2001; Hakkarainen 2001a; Hakkarainen 2001b; and Hietaniemi et al. 2004). An example of a prediction tool is Conetools, developed by SP Technical Research Institute of Sweden. Such models are useful tools for product development and can result in a reduction in costs for SBI sample preparation and testing.

\section{Radiant panel test}

The radiant panel test is used in Europe to regulate flooring products EN ISO 9239-1 (2010) as part of the Euroclass system and in the United States for both floor coverings ASTM E648 (2010) and cellulosic insulation ASTM E970 (2010).

A gas fired radiant panel inclined at $30^{\circ}$ provides a heat flux gradient to a horizontally oriented specimen (size $1050 \mathrm{~mm} \times 230 \mathrm{~mm}$ ) of $\sim 11 \mathrm{~kW} \mathrm{m^{-2 }}$ at one end of the specimen to less than $1 \mathrm{~kW} \mathrm{~m}^{-2}$ at the other end. A pilot flame is applied to the hotter end of the sample to ignite the specimen. The spread of flame along the sample is observed, and is related to the critical heat flux to extinguishment. If after 30 minutes, the specimen is still burning, the position of the flame front at this time is taken as the critical heat flux. As such, a higher critical heat flux indicates improved fire performance as opposed to a lower critical heat flux.

The fire performance of wood products in the Radiant panel test is known to be improved, or at least maintained, by coating systems, e.g. UV cured acrylic, polyurethane, oil systems used by flooring industry, ordinary wood oil and soap mainly used for solid wood floorings (Ostman and Mikkola 2006). Unlike the SBI test, no trends in test performance and specimen density have been found for wood floorings. (Ostman and Mikkola 2006) attributed this to the different influences on flame spread of the gases released as a result of the lower heat flux used in the Radiant panel test. The effect of this on flame spread will differ between wood species depending on e.g. the wood permeability. They did, however, explain that patterns or groupings are observed when the data is examined per wood species.

Some investigations have been completed on correlating the results of the cone calorimeter with the Radiant panel test. No correlations were found to exist by (Tomann 1993) and (Hirschler 1992), and the results of experiments reported by (Ostman and Mikkola 1996) indicated only a slight correlation between the two methods. Hirschler, however, presented a classification scheme based on the ratio of the time to ignition (seconds) and PHRR $\left(\mathrm{kW} \mathrm{m}^{-2}\right)$. High values for this ratio are preferable.

These test methods and the more fundamental thermal analysis techniques all provide useful information about the burning behaviour of timber, and its fire retardant modifications. However, the decomposition and burning behaviour of timber is highly dependent on the thermal and environmental conditions - particularly the sample orientation, the heating rate, the access of oxygen and the sample geometry. For this reason, there is no single objective measure for satisfactorily screening new fire retardant formulations, or optimising fire retardant treatments in preparation for a large-scale regulatory test. Euroclass prediction models, however, mean that the collective output from cone calorimetry can be used to predict the behaviour of a material in the SBI test.

\section{Fire retardants}

\section{Application of fire retardants}

Fire retardants are typically either coated onto the surface of the wood, or impregnated into the wood structure using a vacuum-pressure technique, although other technologies, such as plasma treatments (Pabelina et al. 2012), are being investigated. 
When impregnating, the structure of wood is viewed as being similar to that of a sponge, with cell cavities and cell walls. The aim of fire retardancy is to coat these walls with fire retardant to protect the structure from fire. First, the vacuum removes the air from the cavities to create space for the fire retardant solution, which is then forced deep into the wood under high pressure. The process can be repeated and the parameters adjusted to optimise the treatment dependent on the level of protection and the required depth profile of fire retardant through the wood.

To apply a protective surface coating to wood, it is typically painted, sprayed or dipped into a solution of fire retardant. Superficial treatments, such as paints, are often thought to be attractive for the ease with which they can be applied, and for the comparatively small amount of material required for fire protection. However, the associated re-application requirements and surface damage possibilities are considerable problems for the end-user.

There are numerous approaches by which fire retardants exert their influence on the combustion of wood. They all, however, aim to delay the time to ignition of wood, reduce the rate of heat release during combustion (Hakkarainen et al. 2005) and reduce the surface spread of flames. The modes of action (how they work) are described briefly.

\section{Modes of action}

(Browne 1958) provided an in-depth literature survey on these concepts and summarised them into four basic theories. These are chemical theories, coating theories, thermal theories, and gas theories; however, these strategies are by no means mutually exclusive because two or more of them may be, and probably are, operative in a given case.

Chemical mechanisms are exhibited by most commercial fire retardants for wood where the pyrolysis of wood is directed towards the production of increased char and water, and fewer volatiles. Coating theories suggest that the fire retardant coats the wood fibres to provide a 'blanket' of protection, and prevent the escape of flammable vapours and access of oxygen. Fire retardants displaying thermal action can operate in one of three ways: provide thermal insulation to the wood, absorb the surrounding heat by endothermal reactions, or increase the thermal conductivity of wood in order to dissipate the heat from the wood surface. Gas theories suggest that gases released by the fire retardant either dilute the flammable gases produced by wood to prevent the formation of a flammable mixture, or inhibit chemical reactions in the flame so that combustion is incomplete and less heat is available to sustain burning. Examples of substances used for each of the mechanisms described are outlined in Figure 5.

\section{Potential approaches for fire retarding wood}

Limited progress has been made in the flammability reduction of wood in recent years. Some of the fire retardant timber treatments are two millennia old, where alum was used by Romans. Since then, the synergism between phosphorus and nitrogen, and often boron too, has been widely studied in academia and exploited in various commercial products. Nowadays, many end-users and regulators recognise the hazards presented from the toxicity, smoke and corrosiveness of fire retardant compounds, due to the large volume of attention given to halogenated flame retardants. There is a current contentious toxicity problem with boron and as such, a need for wood products to move away from boron based fire retardants is recognised. From literature describing the fire retardancy of timber and various polymers, the following options show the greatest potential.

\section{Phosphorus based compounds}

Phosphorus based compounds are some of the best known fire retardant treatments for timber. They are considered to work mainly in the condensed-phase, by promoting char formation and depriving the gas-phase of further volatile decomposition products. It is suggested that depending upon the chemistry of the additive, they also work in the gas-phase as flame inhibitors, interrupting the cycle of free radical generation. Some organophosphorus compounds are thought to be sufficiently stable under flaming conditions to work by a physical gas-phase action, in which they act as a blanket to exclude oxygen from the flame (Schartel 2010). Van der Veen and de Boer (2012) have reviewed the properties and toxicity of various phosphorus based fire retardants.

A significant problem of some phosphorus based fire retardants (e.g. monoammonium phosphate, MAP), encountered predominantly in the United States, is the inservice reductions in strength of treated wood products (particularly plywood roof sheathing). This reduction in strength occurs when wood members are exposed to elevated temperatures that are often experienced as a result of solar loads in roof applications (LeVan and Collet 1989). It is attributed to both the initial $\mathrm{pH}$ of the wood and the buffering capacity of the fire retardant system (Winandy 1995). As a result, boron treatments were advocated as the solution to the phosphate problem (Winandy and Herdman 2003; Winandy and McNamara 2003; Winandy and Richards 2003). Of course, given the reclassification of the toxicity of boron, alternative solutions, such as silicon, may require investigation for roofing applications. 


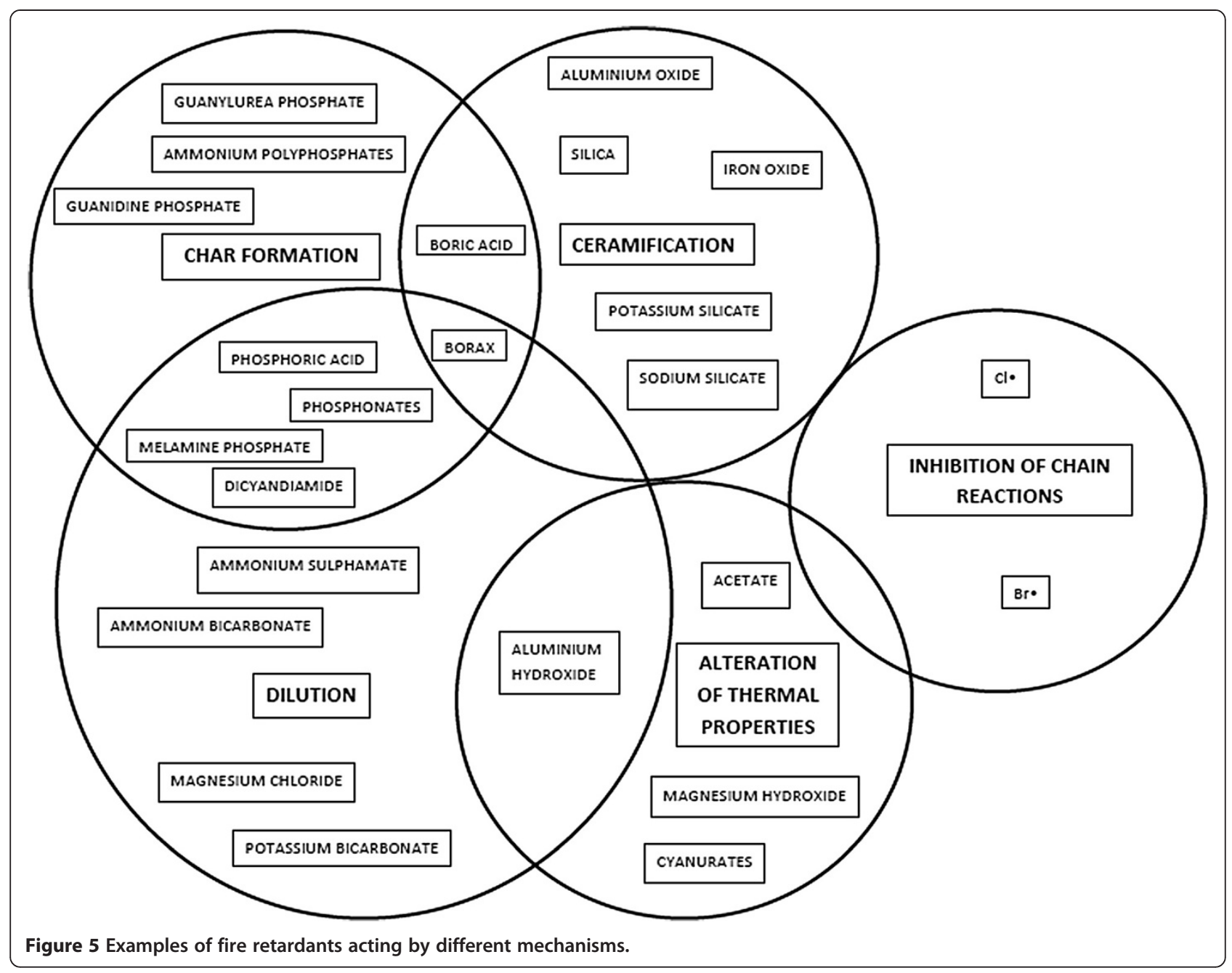

There are a wide range of phosphorus compounds that impart fire retardancy to polymers, due to the existence of several oxidation states of phosphorus, $0,+3$ and +5 (Morgan and Gilman 2012) and the large number of possible structures that can be attached to an atom with five chemical bonds. Elemental red phosphorus, phosphonates and phosphinates are all typical fire retardants; in wood, phosphorus is most commonly used in an inorganic form, typically promoting char formation rather than gas-phase inhibition.

In the condensed-phase, the thermal decomposition of inorganic phosphorus based compounds forms phosphoric acid, which condenses to form pyrophosphate and water. The water released dilutes the oxidising gas-phase and both phosphoric acid and pyrophosphate promote the dehydration of wood's terminal alcohols, crosslinking the cellulose structure, promoting wood's natural ability to char (Kandola et al. 1996). This char layer is responsible for the limitation of oxygen diffusion, thermal insulation of the underlying structure, and the reduction of the volatilisation of the fuel in order to prevent the continuation of the combustion cycle. The endothermic release of water during the condensation of phosphoric acid will also cool the wood and dilute the volatile pyrolysis gases.

Organophosphorus compounds are not often used in commercial wood applications and some are known to have high volatility (Sjogren et al. 2010). Phosphonates are occasionally used for their char promoting abilities, an example of which has been patented by (Hansel et al. 2011). The char residue was increased and the tensile strength of the substrate was not significantly affected. Leachability data of the fire retardant chemical was not provided; however, reference was made to interior uses, e.g. furniture, interior fittings and interior fittings of means of transport.

Organophosphorus compounds are often combined with halogens (Katsuura and Inagaki 1978; Schwenker and Pascu 1958). Stevens et al. (2006) modified pine sawdust with alkyland phenylchlorophosphorus compounds using pyridine. They reported a reduction in the temperature of maximum pyrolysis rate of up to $90^{\circ} \mathrm{C}$ and an increase in char formation of up to $29 \%$. The efficiency of the phenylphosphates was favoured compared to the alkyl analogues and the order 


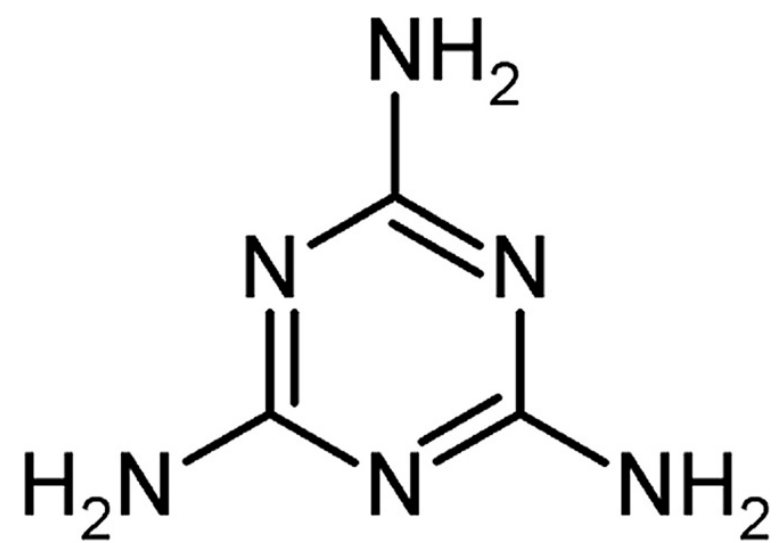

Figure 6 Chemical structure of melamine.

of effectiveness was, expectedly, attributed to the acidity and thermal stability, i.e. phosphate $>$ phosphonate $>$ phosphinate.

There are interests in combining fire retardants with preservative systems to protect against biodegradation (Marney and Russell 2008; Sweet et al. 1996). Marney et al. (2008) showed that coupled with a copper-based preservative, the impregnation of wood with an organophosphorus fire retardant reduced the FIGRA by a further $15 \%$. They also reported an effect of decay resistance and termite control from the fire retardant alone.

\section{Nitrogen based compounds}

Nitrogen based compounds are widely used and growing in popularity due to the lack of environmental concerns, often in combination with phosphorus or sulphur. Their main applications are guanidine phosphates for wood and textiles, melamine (Figure 6) and melamine phosphates or dicyandiamide for intumescents, guanidine sulphamate for wallpapers, melamine for flexible polyurethane foams and melamine phosphonates in polyolefins.

The advantages of nitrogen-containing fire retardants have been reviewed by (Horacek and Grabner 1996). Their role is not fully understood, but they are considered to offer the following means of protection:
- Formation of cross-linked molecular structures in the wood to prevent the formation of volatile gases.

- Dilution of flammable gases produced through the release of nitrogen-containing compounds.

- Synergy with phosphorus-containing fire retardants to reinforce their function.

- Endothermic decomposition with release of ammonia, leaving various larger decomposition products such as melem, melam and melom. These condensation products can form a superficial char layer, which can slow down further thermal decomposition by acting as a stabilising barrier to heat flow.

\section{Phosphorus/nitrogen synergism}

Phosphorus and nitrogen compounds aren't typically used alone in fire retardants for wood. Combinations of the two are preferred due to the synergy observed, which enhances the fire retardancy performance of the individual components (Jiang et al. 2010). Ammonium polyphosphates are one of such combinations (Meng et al. 2009). They are inorganic salts of polyphosphoric acid and ammonia, and are stable, non-volatile compounds. The presence of nitrogen produces a synergistic effect for the phosphorus, whereby the endothermic release of ammonia on heating dilutes the fuel in the gas-phase, potentially delaying ignition. This results in increased flame spread resistance, and favourably lower chemical loadings.

Many long-chain ammonium polyphosphates have low water solubility $\left(<0.1 \mathrm{~g} 100 \mathrm{ml}^{-1}\right)$ allowing for good performance in exterior leachability/weathering studies; however, many shorter chain ammonium polyphosphates are inherently soluble in water and will be leached out during outdoor exposure. As a result of this, fire retardancy will be reduced over time and subsequent treatments will be required. Furthermore, adding such salts can further increase the moisture content of wood, leading to increased susceptibility to microbial attack (Marney et al. 2008).

In a patent by (Diniz 2010), ammonium polyphosphates were mixed with fire retardant and latex inks and applied to wood surfaces for fire protection. The product was applied to the wood surface over the ink, and was suitable for

$$
\begin{array}{ll}
\left(\mathrm{NH}_{4}\right)_{2} \mathrm{HPO}_{4} \longrightarrow \mathrm{NH}_{3}+\mathrm{NH}_{4} \mathrm{H}_{2} \mathrm{PO}_{4} \\
\mathrm{NH}_{4} \mathrm{H}_{2} \mathrm{PO}_{4} \longrightarrow \mathrm{NH}_{3}+\mathrm{H}_{3} \mathrm{PO}_{4} \\
2 \mathrm{H}_{3} \mathrm{PO}_{4} \longrightarrow \mathrm{H}_{2} \mathrm{O}+\mathrm{H}_{4} \mathrm{P}_{2} \mathrm{O}_{7} \\
\mathrm{H}_{4} \mathrm{P}_{2} \mathrm{O}_{7} \longrightarrow 2 \mathrm{H}_{2} \mathrm{O}+\mathrm{P}_{2} \mathrm{O}_{5}
\end{array}
$$

$\left(155^{\circ} \mathrm{C}\right)$ 
both exterior and interior use. Presumably, the product required frequent re-application.

Diammonium phosphate (DAP) and monoammonium phosphate (MAP) are commonly used in fire retardant timber treatments (Grexa and Lubke 2001). They do, however, have the potential to increase the moisture content of wood in humid conditions, promoting fungal decay, and hence are more suited to interior applications where leaching is not an issue. The thermal decomposition of DAP is described in Scheme 1. Similar to phosphorus based fire retardants, the phosphoric acid and phosphorus pentoxide formed react with the hydroxyl groups in wood to cause dehydration. Synergism is exhibited by the phosphorus and ammonia to facilitate the reaction with intermediate carbonyl compounds to form glycosylamines (Liodakis et al. 2006) [Figure 7].

MAP operates similarly to DAP, and it has been reported that retentions of $15 \%$ by weight of wood of MAP increases the char production of Scots pine by $17 \%$ compared to the untreated equivalent (Nussbaum 1988). It is considered that whilst an increase in char yield was quantified, a decrease in the mass transport of flammable volatiles will have been achieved as a result.

Guanylurea phosphate (GUP) [Figure 8] is another inorganic phosphate often used to impart fire retardancy to wood products. As shown by (Fang and Wu 2006), it increases the ignition time of untreated wood, and decreases the PHRR by around $60 \mathrm{~kW} \mathrm{~m}^{-2}$ at an applied heat flux of $35 \mathrm{~kW} \mathrm{~m}^{-2}$. It was also shown by the authors that the production of carbon monoxide and carbon dioxide is significantly decreased by the addition of the material.

Many other researchers have investigated the effectiveness of the mixture (Gao et al. 2006; Wang et al. 2004), where recognition of decreased carbon monoxide/carbon dioxide levels has been made. One study examined the effectiveness of GUP, boric acid and a melamine formaldehyde resin (Markesinis and Katsampas 2009). An average decrease in PHRR of 43\% was recorded and the total smoke production was reduced by $14 \%$. It is expected that whilst

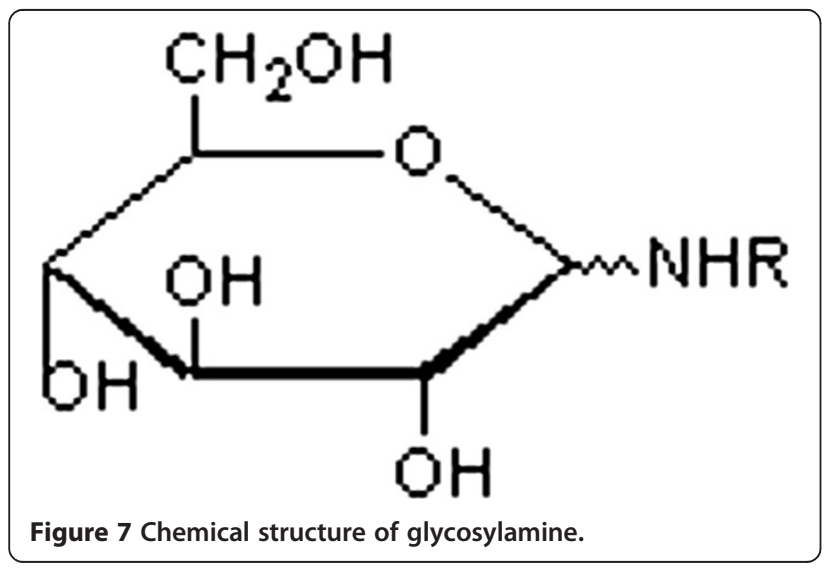

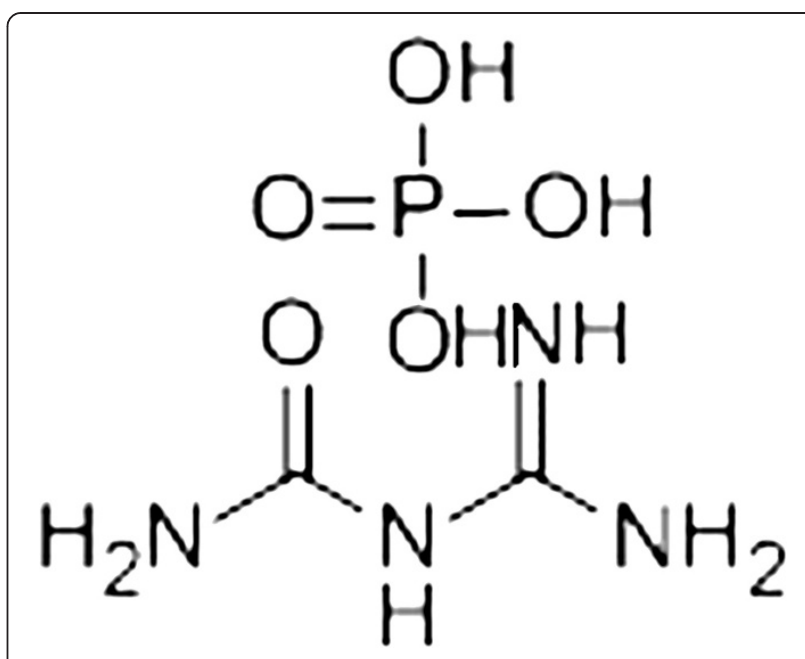

Figure $\mathbf{8}$ Chemical structure of guanylurea phosphate.

the phosphorus and nitrogen will have behaved synergistically to direct the pathway of pyrolysis towards more char and water and fewer flammable volatiles, the boron present will have become molten to form a glass-like barrier on the surface of the wood, stabilising the char and enforcing the mass transport barrier.

The synergism between phosphorus and nitrogen is also observed in organophosphorus compounds. (Rupper et al. 2010) investigated the surface chemistry of cellulose treated with fire retardants containing ethyl ester phosphoramidates. Evidence for a condensed-phase action of the fire retardants was found.

(Lee et al. 2004) showed that phosphoramides, when bonded to cellulose, increase the char yield and lower the weight loss rates in comparison to phosphorus pentoxide and amine treated wood used as comparisons.

Amino resins have received attention from (Gao et al. 2004), where the thermal degradation of wood treated with amino resins, and that treated with amino resins modified with phosphate, was investigated. Samples treated with amino resins only yielded a char residue of $\sim 18 \%$, whereas those treated with amino resins modified with phosphate produced a char residue of $\sim 35 \%$, compared to that of untreated wood $(\sim 7 \%)$. The onset temperature of thermal degradation was lowered by around $20^{\circ} \mathrm{C}$ for wood treated with amino resins, and for those treated with amino resins modified with phosphate, a decrease of around $45^{\circ} \mathrm{C}$ was observed. The authors reported that for wood treated with amino resins only, the main decomposition of samples still occurred at higher temperatures, whereas for samples treated with amino resins modified with phosphates, the decomposition temperatures and heat release were largely decreased. It is considered that phosphorus exhibits the main fire retardancy effect, and without it, amino resins are not significantly effective in catalysing the thermal decomposition of wood. 
In another study (Gao et al. 2005), wood was treated with guanidine dihydrogen phosphate, diguanidine hydrogen phosphate, guanidine carbonate and guanidine nitrate and analysed using TGA. Char yields were increased compared to untreated wood by approximately $60 \%, 55 \%, 20 \%$ and $25 \%$, respectively, which effectively demonstrates the synergism by phosphorus of nitrogen based fire retardants.

\section{Silicon based compounds}

Silicon compounds are a relatively new addition to the list of recognised fire retardants for wood and are better known for use in plastics (Gilman et al. 1999). Difficulties have arisen, however, in effectively impregnating the silicon into the wood, and keeping it there. As a result, they are often applied as coatings rather than impregnation treatments. When silicon compounds are applied as coatings, they dry to form a relatively hard, smooth layer that is resistant to heat, fire, abrasion and corrosion. When an external heat source is applied under oxygen, an inorganic silica residue is formed. This residue serves as an insulating blanket, which at higher temperatures will also act as a radiation shield, delaying the volatilization of the pyrolysis products. This reduces the number of volatiles available as fuel in the gaseous phase, hence preventing heat from circulating back into the wood surface. The underlying wood is also insulated from the incoming heat. (Kashiwagi and Gilman 2000) have extensively reviewed the fire retardancy of silicon-based compounds.

Silicones are silicon based elastomers, which have relatively low HRR, minimal sensitivity to external heat flux, low yields of carbon monoxide and a slow burn rate (Hamdani et al. 2009).

Fumed and precipitated silica are often used as reinforcing fillers, however they do not display chemical fire retardancy as they do not decompose to evolve water or carbon dioxide or promote cross-linking etc. Instead, research has shown that they act to lower the HRR and MLR in the condensed-phase. The fire retardancy imparted by various forms of silica (silica, silica gel, silica fume and fused silica) to polypropylene and polyethylene oxide has been reviewed by (Kashiwagi et al. 2000). The authors confirmed a condensed-phase mechanism: accumulation of silica at the sample surface acting as an insulation layer, radiation shield and a mass transport barrier.

For siloxane based compounds, it has been found that as the length of the siloxane chain increases, the time to ignition in a cone calorimetry test decreases. This has been attributed to the increasing amount of combustible hydrocarbon in the sample with increasing chain length (Connell et al. 2000). Similar to other ceramic coating materials, the weight of residue at the end of a burn is proportional to the polymer molecular weight (Grassie et al. 1980). Glassel and Mellema (2006) revealed a formulation comprising a siloxane copolymer that reduced the amount of free water bound to the lignocellulosic structures of the treated wood. This, in turn, reduced the formation of steam within the heated wood. This steam tends to sweep volatile, flammable gases out of the vascular system of the wood and into the air where they have sufficient oxygen to ignite.

Crews et al. (1993) not only described the application of one silicon based layer to wood, but several layers of various silicate compounds. The wood is first coated in one or more layers of sodium silicate, protected by an outer coating of silicon dioxide, achieved through the exposition of the sodium silicate coated wood to a solution of phosphoric acid. Decreased combustibility and smoke production were reported. Similarly, Slimak and Slimak (2004) used sodium silicate (waterglass) as a fire retardant coating for wood products, which was further coated with a micro-layer of silicon oxide in order to serve as an effective moisture barrier and protector against long-term deterioration. The application of silicon dioxide reduced the water solubility of sodium silicate, allowing its use in exterior applications.

There have been various studies (Giudice and Pereyra 2007; 2010; Pereyra and Giudice 2008; Pereyra et al. 2009) on the use of alkaline silicates as impregnation treatments for wood. Whilst the necessity for manipulation of the water-solubility of such alkaline silicates was highlighted by these papers, very good performances were obtained by those with the purpose of improving the behaviour of wood against fire. Giudice and Pereyra (2010) showed that, through the use of oxygen index and tunnel tests [ASTM E84 2013] (the regulatory test for interior flammability of building materials in the United States), the treatment of wood with alkaline silicates provides several significant advantages: high fire retardancy, low thermal expansion, reduced smoke production, and low cost.

Combinations of silicon and phosphorus have proved popular in the fire retardancy community (Kandola et al. 1996), in addition to silicon, phosphorus and nitrogen mixtures (Li et al. 2006; Yang et al. 2012). The synergism is generally explained as a combination of the individual effects of each of the three additives: phosphorus provides the effective char formation, nitrogen produces non-combustible gases acting as diluents, and silicon offers thermal stability to the substrate by forming a protective layer over the forming char throughout decomposition. The white deposit of silicon dioxide covering the surface of the char will act as a radiant heat shield and help to reduce the rate of oxidation of the char. (Lally 2010) described a method whereby a cellulose based substrate was treated with an aqueous solution of potassium phosphate, magnesium oxide and silica. 
Although silicon is typically applied to the surface of the wood through the utilisation of a brush, spray or air gun, one study (Eastman et al. 2009) described the use of supercritical $\mathrm{CO}_{2}$ to incorporate various silicones into Aspen samples. It was shown to be effective; however, it must be noted that using supercritical $\mathrm{CO}_{2}$ is an expensive method. In recent years, sol-gel processes have also become recognised for the purposes of incorporating fire retardants into products. The process comprises hydrolysis and condensation reactions that lead to the formation of inorganic or organic-inorganic coatings. This technique is well documented for different polymers (Qu et al. 2012) (Chiang and Ma 2004), and now also for cotton textiles (Alongi et al. 2012).

\section{Inorganic metal hydrates and carbonates}

Inorganic metal hydrates and carbonates decompose endothermically, diluting the pyrolysis gases given off by the substrate. Examples include aluminium hydroxide, magnesium hydroxide and basic magnesium carbonate (hydromagnesite) (Hull et al. 2011).

Hydrates act as a chemical heat sink for the wood by absorbing some of the heat of combustion and lowering the temperature of the material near the flame during their endothermic decomposition and as a result, the wood is cooled and the time to ignition is increased. The water vapour or carbon dioxide released by the hydroxide or carbonate (Table 2) dilutes the gaseous reactants in the flame. Sufficient fire-proofing properties, however, may require unachievably high loadings of the treatment, and as such are rarely used in the protection of timber products. Nevertheless, aluminium hydroxide has long been a fire retardant ingredient in fiberboard (LeVan 1984); its thermal decomposition is shown in Scheme 2.

Carbonates and hydrogen carbonates are known to have very high efficiency as gas-phase flame retardants. Potassium carbonate is reported as a compound with a high fire retardant efficiency for wood materials (Dobele et al. 2007; Kadir et al. 2007). It has a relatively high decomposition temperature of $800^{\circ} \mathrm{C}$ and serves as a catalyst to the dehydration reaction of wood to increase the production of char, water and $\mathrm{CO}_{2}$. However, the material is unable to prevent the depolymerisation reaction of wood effectively, particularly at high concentrations, and also causes the evolution of CO (Dobele et al.

Table 2 Properties of some inorganic metal hydrates (Hollingbery, 2011)

\begin{tabular}{llll}
\hline & $\mathbf{A l}_{\mathbf{2}}(\mathbf{O H})_{\mathbf{3}}$ & $\mathbf{M g}(\mathbf{O H})_{\mathbf{2}}$ & $\mathbf{A l O}(\mathbf{O H})$ \\
\hline Bound water (\%) & 34.6 & 31 & 15 \\
$\begin{array}{l}\text { Minimum decomposition } \\
\text { temperature }\left({ }^{\circ} \mathrm{C}\right)\end{array}$ & 180 & 300 & 340 \\
Enthalpy of decomposition $\left(\mathrm{J} \mathrm{g}^{-1}\right)$ & 1170 & 1244 & 612 \\
\hline
\end{tabular}

2007). As such, potassium carbonate is only used in low concentrations.

\section{Intumescents}

Recently, a new form of intumescent fire retardant coatings for wood-based materials was introduced (Chou et al. 2009). The authors investigated the usefulness of an artificial graphite powder and a sericrite $\left(\mathrm{Al}_{4}(\mathrm{OH})_{4}\left(\mathrm{KAl}-\mathrm{Si}_{3} \mathrm{O}_{10}\right)_{2}\right)$, and a mixture of the two on plywood. The intumescent fire retardant coating contained $19.8 \%$ of the fire retardant, $15 \%$ of the dehydration agent, $18 \%$ of the foaming agent, $7.2 \%$ of the resin binder and $40 \%$ of the solvent, was prepared and applied to the surface of plywood. They showed that when sericrite was in excess of $75 \%$ in the fire retardant composition, the mixture obtained the lowest flammability grade possible in Taiwan Standard CNS 7614. Furthermore, for sericrite to be effective in inhibiting combustion, carbonising agents, such as graphite powder, are not required.

Regular intumescent coatings are now also used in combination with metal foil. This combination, consisting of a thin metal sheet or a ceramic layer on top of the intumescent coating, serves as a gas barrier to the intumescent coating (Hakkarainen 2010). Ignition and charring are prevented and delayed by these methods and the endurance of typical fire temperatures by the materials is retained. No differences in adhesion to the wood surface were reported.

\section{Expandable graphite}

Incorporating expandable graphite into the structure of polymers has been of recent interest (Duquesne et al. 2003; Meng et al. 2009; Zhu et al. 2011). Expandable graphite is an interesting material produced by the intercalation of acid, typically sulphuric, between the layers of graphite. When heated to around $200^{\circ} \mathrm{C}$, gas and vapour is released resulting in rapid expansion between the layers to produce graphitic worm-like growths visible to the naked eye. Since all the evolved gases and water vapour are non-flammable, they will dilute the fuel in the gas-phase. The main benefit of expandable graphite however is considered to be the production of a fluffy intumescent layer of carbon that functions as a barrier to heat and gas, slowing down the typical cycle of heat from flaming combustion generating more gaseous fuel.

One study, involving a wood-plastic composite (Naumann et al. 2012) added 15\% w/w of expandable graphite into a wood-polypropylene composite (50:30\% $\mathrm{w} / \mathrm{w}$ respectively). The remaining $5 \%$ was talc. Samples were tested in the cone calorimeter and compared to the same composite treated with $15 \% \mathrm{w} / \mathrm{w}$ ammonium polyphosphate. Figure 9 depicts the results from the PHRR, THR and char residue. The increase in char residue was attributed to the expandable graphite adding a layer of 


$$
2 \mathrm{Al}_{2}(\mathrm{OH})_{3}(\mathrm{~s}) \longrightarrow \mathrm{Al}_{2} \mathrm{O}_{3}(\mathrm{~s})+3 \mathrm{H}_{2} \mathrm{O}(\mathrm{g})
$$

Scheme 2 Thermal decomposition of aluminium hydroxide.

expanded graphite 'worms' to the residue of the woodplastic composite. This expansion prevented underlying material from undergoing complete combustion, which resulted in large decreases in PHRR and THR, even when compared to the samples treated with ammonium polyphosphate.

Liu (2000) patented a fire retardant coating composition containing expandable graphite particles, a solid absorbent material, a polymeric binder, a carbonific material, a blowing agent, a solvent, and a rheology modifier. Reasonable fire performance data was provided by the examples provided.

Considering that expandable graphite functions as a physical barrier to burning, it may be suitable in timber, provided coating applications are preferred and the natural appearance of the wood is not required. If impregnation applications are preferred, however, difficulties may be encountered regarding the penetration of expandable graphite into the timber structure. This is due to the small particle size required for adequate penetration into its structure, the large particle size of the expandable graphite, and its need to be free to expand (which is unlikely within the timber matrix).

\section{Nanocomposites}

In the future, nanocomposite coatings may be applied to improve the reaction to fire performance of wood and wood-based products. In this approach, nanometric scale particles are added to a macroscopic material to produce new properties (Laoutid et al. 2009; Morgan and Gilman
2012; Sertsova et al. 2010). Intumescent polymer-clay nanocomposites have been applied to protect polymers and steel (Laoutid et al. 2009; Morgan and Gilman 2012), but studies for wood products are not known to the authors.

Nanosized multilayer fire retardant structures can be engineered on textiles by the Layer by Layer technology. In this technique, several layers of positively and negatively charged fire retardant additives are applied to the surface of a material using layer by layer assembly by dipping or spraying. The technology is currently being studied for fabrics by Carosio et al. (2011) and Alongi et al. (2013a). The latter authors investigated the application of silicon based fire retardants using Layer by Layer technology on the fire retardancy of cotton fibres. The technology was performed in three ways: dipping, vertical spraying and horizontal spraying. The authors reported that horizontally sprayed samples exhibited the best reaction to fire performance, in terms of time to ignition, HRR and THR using cone calorimetry. This result was attributed to the production of a continuous, homogenous coating of silica when horizontal spraying was utilised, compared to dipping and vertical spraying. It is expected that similar results would be achieved with wood.

\section{Simultaneous gas- and solid-phase}

Howell (2008) has investigated the possibility of development of additives for polymeric materials that could simultaneously promote gas-phase and solid-phase flame retardancy, in order to improve the cost effectiveness

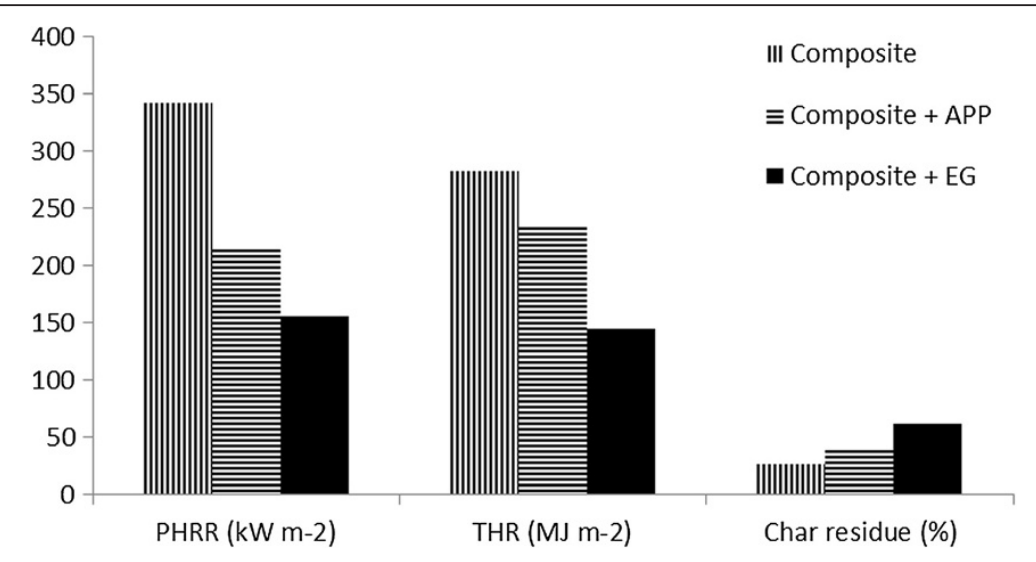

Figure 9 Cone calorimeter measurements of wood-polypropylene composites alone, treated with ammonium polyphosphate (APP) and expandable graphite (EG). 
and environmental-soundness of fire retardants. A variety of approaches were reported, containing both halogen and either phosphorus or nitrogen, that effectively displayed dual functional behaviour. The applicability of this to wood materials is unknown.

\section{Metallic salts}

The influence of magnesium chloride and nickel chloride on the thermal decomposition behaviour of Birch was recently investigated by TGA and pyrolysis-gas chromatography-mass spectrometry (Khelfa et al. 2013). The authors reported that magnesium chloride was the most effective of the two. Increased levels of furanic and pyranic compounds were found at lower temperatures, which, when coupled with an increased char production and decreased pyrolysis temperature, was attributed to the catalysation of the primary dehydration of cellulose by the metal salt. The potential of these metal salts is, however, limited by their corrosivity and the possibility of forming hydrogen chloride on decomposition.

\section{Whey proteins}

Given that whey proteins are known to possess remarkable oxygen barrier properties and a high affinity for water (Alongi and Malucelli 2013), they were recently investigated by (Bosco et al. 2013) to study their effect on the thermal degradation of cotton. A beneficial effect was observed.

Two proteins were applied as coatings to the textile and the effects were studied using TGA. The char residue at $700^{\circ} \mathrm{C}$ in a test atmosphere of nitrogen of the cellulose coated with one of the whey proteins was increased by $125 \%$ from the untreated equivalent. Similarly, the onset of decomposition was lowered by the treatment (from $329^{\circ} \mathrm{C}$ to $276^{\circ} \mathrm{C}$ ). These results were attributed to the sensitisation of the cellulose decomposition.

Although the high water affinity exhibited by whey proteins could present a problem for wood treatment, the environmental soundness and cost-effectiveness of the treatment could lead to further work for cellulosic substrates.

The authors of the work also contributed to studies investigating the fire retardant properties of deoxyribonucleic acid (DNA) from herring sperm on cotton fabrics (Alongi et al. 2013). Results showed that the cotton was self-extinguishing when $10 \%$ DNA was used, and it was resistant to a flame heat flux of $35 \mathrm{~kW} \mathrm{~m}^{-2}$ when $19 \%$ DNA was used. The efficiency was attributed to the intumescent mechanism exhibited by the combination of phosphorus (acid producer), deoxyribose units (blowing agent) and nitrogen-containing bases (releasing ammonia). The unlikely feasibility of this for wood on a commercial scale, however, is recognised.

\section{Concluding remarks}

No single screening tool can be used to assess the degradation and flammability properties of the various mechanisms available. MCC will not show the effect of a surface coating since it is concerned with bulk burning. Similarly, cone calorimetry is unable to represent surface flame spread of a test specimen whilst the LIFT apparatus does have this ability. As a result, a combination of test apparatuses (or a test apparatus/prediction model combination) must be used in the development of fire retardant timber treatments, and the results evaluated together. For example, predictive models can be used in combination with the collective output from the cone calorimeter to predict the behaviour of a material in the SBI test, thus predicting a product's Euroclass.

A broad range of fire retardant treatment systems for wood have been studied throughout recent years and many others are currently under development. Combinations of phosphorus and nitrogen continue to prove themselves as very powerful solutions for wood-based applications, whilst silicon based compounds are continually under improvement. It is likely that phosphorus and nitrogen combinations will remain at the forefront of fire retarding timber and as such novel application techniques, e.g. Layer by Layer technology, show potential for industrial application and may further improve the performance of these long standing chemicals. Inorganic fillers and silicon are suggested as possible direct replacements to boron free systems, operating via a similar mechanism and combining economy, a reduction in flammability, and smoke inhibition with low toxicity of fume. Looking beyond phosphorus, nitrogen and silicon, however, there is significant scope for increased effectiveness from various options. Firstly, the use of expandable graphite can be evaluated for coatings, but its large size and mode of action suggest it would be unsuitable for penetrative treatments. In addition, combinations of intumescent coatings and thin metal layers show increased times to ignition for timber. Insoluble nano-sized chemicals may offer the potential of the greatest fire retardant effect for the lowest loading level. These materials have shown excellent effects in the laboratory for polymers, but improvement needs to be made in the industrialisation of the high dispersion levels required.

Whilst the addition of a fire retardant to wood may improve its flammability properties, it may come at the expense of intrinsic properties such as strength or increased smoke production. Fire retardants must, therefore, be formulated for best overall performance, including consideration of the hydrophilicity, glueability, paintability and corrosion effects of the chemical to be used in conjunction with wood. The fire retardancy of wood remains a very complex scientific problem for 


\section{which close collaboration between different disciplines is required.}

\section{Competing interests}

The authors declare that they have no competing interests.

\section{Authors' contributions}

LAL wrote and revised the manuscript. TRH contributed to the initial and revised manuscript. Both authors read and approved the initial and final manuscripts.

\section{Acknowledgements}

This study was supported by a grant from the Knowledge Transfer Partnership Scheme, of the UK's Technology Strategy Board.

Received: 26 April 2013 Accepted: 5 August 2013

Published: 3 September 2013

\section{References}

Agency for Toxic Substances and Disease Registry (2010) Toxicological profile for Boron. US Department of Health and Human Services, Atlanta, GA

Alongi J, Malucelli G (2013) Heat and moisture transfer in sol-gel treated cotton fabrics. J Therm Anal Calorim 11:459-465

Alongi J, Colleoni C, Malucelli G, Rosace G (2012) Hybrid phosphorus-doped silica architectures derived from a multistep sol-gel process for improving thermal stability and flame retardancy of cotton fabrics. Polymer Degradation and Stability 97:1334-1344

Alongi J, Carletto RA, Di Blasio A, Cuttica F, Carosio F, Bosco F, Malucelli G (2013a) Intrinsic intumescent-like flame retardant properties of DNA-treated cotton fabrics. Carbohydr Polym 96:296-304

Alongi J, Carosio F, Frache A, Malucelli G (2013b) Layer by layer coatings assembled through dipping, vertical or horizontal spray for cotton flame retardancy. Carbohydrate Polymers 92:114-119

ASTM D7309 (2011) Standard Test Method for Determining Flammability of Plastics and Other Solid Materials using Microscale Combustion Calorimetry. ASTM International, West Conshohocken, PA

ASTM E119 (2012) Standard test methods for fire tests of building construction and materials. ASTM International, West Conshohocken, PA

ASTM E648 (2010) Standard test method for critical radiant flux of floor-covering systems using a radiant heat energy source. ASTM International, West Conshohocken, PA

ASTM E84 (2013) Standard test method for surface burning characteristics of building materials. ASTM International, West Conshohocken, PA

ASTM E970 (2010) Standard test method for critical radiant flux of exposed attic floor insulation using a radiant heat energy source. ASTM International, West Conshohocken, PA

Babrauskas V (2002) Ignition of wood: a review of the state of the art. Interflam :71-88

Babrauskas V, Grayson SJ, Tran HC (1992) Heat release in fires: experimental data on wood materials. Journal of Fire Protection Engineering 12:163-189

Bergman R, Cai Z, Carll CG, Clausen CA, Dietenberger MA, Falk RH, Frihart CR, Glass SV, Hunt CG, Ibach RE, Kretschmann DE, Rammer DR, Ross RJ (2010) Wood handbook-wood as an engineering material. Forest Products Laboratory, Madison, Wl

Bland KE (1991) Behaviour of wood exposed to fire: a review and expert judgement procedure for predicting assembly failure. Dissertation, Worcester Polytechnic Institute

Bosco F, Carletto RA, Alongi J, Marmo L, DiBlasio A, Malucelli G (2013) Thermal stability and flame resistance of cotton fabrics treated with whey proteins. Carbohydr Polym 94:372-377

Browne FL (1958) Theories of the combustion of wood and its control - a survey of the literature, FPL report number 2136. Forest Products Laboratory, Madison, WI

BS 7990 (2003) Tube furnace method for the determination of toxic product yields in fire effluents. British Standards Institution, United Kingdom

Carling O (1990) Fire engineering design of timber structures, Report I 9004018, The Swedish Institute for Wood Technology. Research, Stockholm, Sweden

Carosio F, Laufer G, Alongi J, Camino G, Grunlan JC (2011) Layer-by-layer assembly of silica-based flame retardant thin film on PET fabric. Polymer Degradation and Stability 96:745-750
Carpenter K, Janssens M (2005) Using heat release rate to assess combustibility of building products in the cone calorimeter. Fire Technol 41:79-92

Chiang CL, Ma CCM (2004) Synthesis, characterisation, thermal properties and flame retardance of novel phenolic resin/silica nanocomposites. Polymer Degradation and Stability 83:207-214

Chou CS, Lin SH, Wang Cl (2009) Preparation and characterisation of the intumescent fire retardant coating with a new flame retardant. Advanced Powder Technology 20:169-176

Connell JE, Metcalfe E, Thomas MJK (2000) Silicate-siloxane fire retardant composites. Polym Int 49:1092-1094

Crews NC, Young DA, Young LA (1993) Process of protecting metallic and wood surfaces using silicate compounds. US Patent 5:205,874, 27 Apr 1993

Crompton TR (1989) Analysis of polymers: an introduction. Pergamon Press, Oxford, U.K

Dietenberger M (2002) Update for combustion properties of wood components. Fire and Materials 26:255-267

Diniz OL (2010) Flame retardant for wood application. US Patent, US, 2010/ 0112228 A1, 6 May 2010

Dobele G, Urbanovich I, Zhurins A, Kampars V, Meier D (2007) Application of analytical pyrolysis for wood fire protection control. J Anal Appl Pyrolysis 79:47-51

Duquesne S, Le Bras M, Bourbigot S, Delobel R, Vezin H, Camino G (2003) Expandable graphite: a fire retardant additive for polyurethane coatings. Fire and Materials 27:103-117

Eastman SA, Lesser AJ, McCarthy TJ (2009) Supercritical CO2-assisted, siliconemodified wood for enhanced fire resistance. J Mater Sci 44:1275-1282

EN ISO 9239-1 (2010) Reaction to fire tests for floor coverings - Part 1: determination of the burning behaviour using a radiant heat source. International Organization for Standardization, Switzerland

European Borates Association (2010) Comment on annex XV dossiers, Federchimica Aispec http://gail.federchimica.it/Libraries/Documenti_vari/ EBA_comments_Annex_XV_100104_final.sflb.ashx, accessed July 2013

European Chemicals Agency (2008) Transitional annex XV dossier based on regulation (EC) No 1272/2008. Boric acid, Austria

European Chemicals Agency (2010a) Annex XV dossier, proposal for identification of a substance as substance of very high concern (SVHC) based on regulation (EC) No 1272/2008. Boric acid, Germany/Slovenia

European Chemicals Agency (2010b) Draft support document for identification of boric acid as a substance of very high concern because of its CMR properties based on regulation (EC) No 1272/2008

European Chemicals Agency (2013) Proposal for harmonised classification and labelling based on regulation (EC) no 1272/2008, vol 2, 5th edn. Boric acid, CLH Report submitted by Poland

Fang K, Wu W (2006) In: Huang P, Wang Y, Li S, Zheng C, Mao Z (eds) Investigation on flammability of wood treated with chemicals. Proceedings of the International Symposium on Safety Science and Technology, China

Friedman R, Friedman J, Linvelle L (2003) Principles of fire protection chemistry and physics: Part II - fire protection chemistry and physics. In: Fire Characteristics: Solid Combustibles, 3rd edn. Jones and Bartlett Publishers, London

Friquin KL (2010) Material properties and external factors influencing the charring rate of solid wood and glue-laminated timber. Fire and Materials 35:303-327

Gao M, Zhu K, Sun YJ, Sun C (2004) Thermal degradation of wood treated with amino resins and amino resins modified with phosphate in nitrogen. Journal of Fire Sciences 22:505-515

Gao M, Ling B, Yang S, Zhao M (2005) Flame retardance of wood treated with guanidine compounds characterised by thermal degradation behaviour. J Anal Appl Pyrolysis 73:151-156

Gao M, Niu J, Yang R (2006) Synergism of GUP and boric acid characterized by cone calorimetry and thermogravimetry. Journal of Fire Sciences 24:499-511

Gilman JW, Kashiwagi T, Harris RH, Lomakin S, Lichtenhan JD, Bolf A, Jones P (1999) Char enhancing approaches to flame retarding polymers. In: Malden MA, Malaika S, Golovoy A, Wilkie CA (eds) Chemistry and technology of polymer additives. Blackwell Science Inc, Malden

Giudice CA, Pereyra AM (2007) Fire resistance of wood impregnated with soluble alkaline silicates. Research Letters n Materials Science doi:10.1155/RLMS, Article ID 31956, e-ISSN 1687-6830

Giudice CA, Pereyra AM (2010) Silica nanoparticles in high silica/alkali molar ratio solutions as fire retardant impregnants for woods. Fire and Materials 34:177-187

Glassel D, Mellema GE (2006) Fire retardant for wood products. US Patent, US, 2006/0131549 A1, 22 June 2006

Grassie N, Francey KF, Macfarlane IG (1980) The thermal degradation of PDMS Part 4: poly(dimethyl/diphenyl siloxane). Polym Degrad Stab 2:67-83 
Green J (1996) Mechanisms flame retardancy and smoke suppression - a review. Journal of Fire Sciences 14:426-442

Grexa O, Lubke H (2001) Flammability parameters of wood tested on a cone calorimeter. Polym Degrad Stab 74:427-432

Hakkarainen T (2001a) Correlation studies of SBI and cone calorimeter test results, 1st edn. Interflam, Edinburgh, UK, pp 519-530

Hakkarainen T (2001b) Rate of heat release and ignitability indices in predicting SBI test results. Journal of Fire Sciences 19:284-305

Hakkarainen T (2010) Thin thermal barriers for wood based products to improve fire resistance, VTT research report VIT-R-07061-09. VIT Technical Research Centre of Finland: :1-11

Hakkarainen T, Kokkala MA (2001) Application of a one-dimensional thermal flame spread model on predicting the rate of heat release in the SBI test. Fire and Materials 25:61-70

Hakkarainen T, Mikkola E, Ostman B, Tsantaridis L, Brumer H, Piispanen P (2005) Innovative eco-efficient high fire performance wood products for demanding applications. VIT, Finland; SP Tratek, Sweden; KTH Biotechnology, Sweden, pp 1-47

Hamdani S, Longuet C, Perrin D, Lopez-Cuesta JM, Ganachaud F (2009) Flame retardancy of silicone-based materials. Polymer Degradation and Stability 94:465-495

Hansel JG, Mauerer O, Gartnerr M (2011) Flame retardant wood based materials. US Patent, US, 2011/0108782 A1, 12 May 2011

Hietaniemi J, Hakkarainen T, Mikkola E (2004) Modern tools for estimating fire performance of wood based products. COST Action E29: International Symposium of Advanced Timber and Timber-Composite Elements for Buildings, Florence

Hirata T, Kawamoto S, Nishimoto T (1991) Thermogravimetry of wood treated with water-insoluble retardants and a proposal for development of fire retardant wood materials. Fire and Materials 15:27-36

Hirschler MM (1992) Smoke and heat release and ignitability as measures of fire hazard from burning of carpet tiles. Fire Safety Journal 18:305-324

Hollingbery $L$ (2011) Decomposition and fire retardancy of naturally occurring mixtures of huntite and hydromagnesite. PhD thesis: University of Central Lancashire, UK

Horacek H, Grabner R (1996) Advantages of flame retardants based on nitrogen compounds. Polymer Degradation and Stability 54:205-215

Howell BA (2008) Development of additives possessing both solid-phase and gas-phase flame retardant additives. Polymer Degradation and Stability 93:2052-2057

Hull TR, Witkowski A, Hollingbery L (2011) Fire retardant action of mineral fillers. Polymer Degradation and Stability 96:1462-1469

ISO 5658-2 (2006) Reaction to fire tests - spread of flame. Part 2 - lateral spread on building and transport products in vertical configuration. International Organization for Standardization, Switzerland

ISO 5659-2 (2012) Smoke production. Part 2 - determination of the optical density of smoke produced from a horizontally positioned test specimen subjected to a specific thermal radiation in a sealed chamber. International Organization for Standardization, Switzerland

ISO 5660-1 (2002) Reaction-to-fire tests -- heat release, smoke production and mass loss rate -- Part 1: heat release rate (cone calorimeter method). International Organization for Standardization, Switzerland

ISO 834 (2012) Fire resistance tests - elements of building construction. International Organization for Standardization, Switzerland

Janssen S (2005) Brominated flame retardants: Rising levels of concern. Healthcare without harm, Arlington VA

Jiang J, Li J, Hu J, Fan D (2010) Effect of nitrogen phosphorus flame retardants on thermal degradation of wood. Construction and Building Materials 24:2633-2637

Jonsson R, Pettersson O (1958) Timber structures and fire - a review of the existing state of knowledge and research requirements, Document D3:1985, Swedish Council for Building Research. Stockholm, Sweden

Kadir O, Abdullah Cl, Erol B, Salih A (2007) The effect of potassium carbonate, borax and wolmanit on the burning characteristics of oriented strandboard (OSB). Construct Build Mater 21:1457-1462

Kandola BK, Horrocks AR, Price D, Coleman GV (1996) Flame retardant treatments of cellulose and their influence on the mechanism of cellulose pyrolysis. Journal of Macromolecular Science 36:721-794

Karpovic Z, Sukys R, Gudelis R (2012) Toxicity research of smouldering and flaming pine timber treated with fire retardant solutions. J Civ Eng Manag 18:600-608
Kashiwagi T, Gilman JW (2000) Grand A F, Wilkie C A (eds), Fire retardancy of polymeric materials. Marcel Dekker Inc, New York

Kashiwagi T, Gilman JW, Butler KM, Harris RH, Shields JR, Asano A (2000) Flame retardant mechanism of silica gel/silica. Fire and Materials 24:277-289

Katsuura K, Inagaki N (1978) Flame retardant properties of cellulose phenylthiophosphonate. J Appl Polym Sci 22:679-687

Khelfa A, Bensakhria A, Weber JV (2013) Investigations into the pyrolytic behaviour of birch wood and its main components: primary degradation mechanisms, additivity and metallic salt effects. J Anal Appl Pyrolysis 101:111-121

Kim HS, Kim S, Kim HJ, Yang HS (2006) Thermal properties of bio-flour-filled polyolefin composites with different compatibilizing agent type and content. Thermochim Acta 451:181-188

Lally TJ (2010) Fire retardant method for manufacturing fire retardant cellulosebased. US Patent, US, 7776179 B2, 17 Aug 2010

Laoutid F, Bonnaud L, Alexandre M, Lopez-Cuesta JM, Dubois PH (2009) New prospects in flame retardant polymer materials: from fundamentals to nanocomposites. Materials Science and Engineering R 63:100-125

Lee HL, Chen GC, Rowell RM (2004) Thermal properties of wood reacted with a phosphorus pentoxide-amine system. J Appl Polym Sci 91:2465-2481

LeVan SL (1984) Chemistry of fire retardancy. In: Rowell R (ed) The Chemistry of Solid Wood, vol 207. American Chemical Society, Washington, pp 531-574

LeVan SL, Collet M (1989) Choosing and applying fire-retardant treated plywood and lumber for roof designs. Gen Tech Rep. FPL-GTR-62. USDA Forest Services, Madison, WI

Li Q, Jiang P, We P (2006) Synthesis, characteristic and application of new flame retardant containing phosphorus, nitrogen and silicon. Polymer Engineering and Science 46:344-350

Liodakis S, Vorisis D, Agiovlasitis IP (2006) Testing the retardancy effect of various inorganic chemicals on smouldering combustion of Pinus halepensis needles. Thermochim Acta 444:157-165

Liu F (2000) Fire retardant coating composition. US Patent 6.084.008, 4 Jul 2000

Lyon RE, Walters RN (2002) A microscale combustion calorimeter. US Department of Transport, Washington, Report Number: DOT/FAA/AR-01/117

Lyon RE, Walters RN (2004) Pyrolysis combustion flow calorimeter. J Anal Appl Pyrolysis 71:27-46

Markesinis K, Katsampas I (2009) Innovative and competitive chemical technology for production of fire retardant wood based panels. Chimar Hellas, SA, pp 1-13

Marney DCO, Russell LJ (2008) Combined fire retardant and wood preservative treatments for outdoor wood applications - a review of the literature. Fire Technol 44:1-14

Marney DCO, Russell LJ, Mann R (2008) Fire performance of wood (Pinus radiata) treated with fire retardants and a wood preservative. Fire and Materials 32:357-370

McDonald KA, Kretschmann DE (1999) Commercial Lumber. In: Wood Handbook - Wood as an engineering material. Forest Products Laboratory, Madison

McNaughton GC (1945) Ignition and charring temperatures of wood. Wood products 50:21-22

Meng XY, Ye L, Zhang XG, Tang PM, Tang JH, Ji X (2009) Effects of expandable graphite and ammonium polyphosphate on the flame-retardant and mechanical properties of rigid polyurethane foams. J Appl Polym Sci 114:853-863

Merryweather G, Spearpoint MJ (2008) Ignition of New Zealand wood products in the LIFT, RIFT and ISO 5657 apparatus using the ASTM E 1321-97 protocol. Journal of Fire Sciences 26:63-88

Messerschmidt B, Van Hees P, Wickstrom U (1999) Prediction of SBI (Single Burning Item) test results by means of cone calorimeter test results. Interflam 1999:11-22, Proceedings, Edinburgh

Mikkola E (1990) Charring of wood, VTT Research Report 689, VIT Technical Research Centre of Finland. Espoo, Finland

Morgan AB, Gilman JW (2012) An overview of flame retardancy of polymeric materials: application, technology and future directions. Fire and Materials. doi:10.1002/fam.2128

Naumann A, Seefeldt H, Stephan I, Braun U, Knoll M (2012) Material resistance of flame retarded wood-plastic composites against fire and fungal decay. Polym Degrad Stab 97:1189-1196

Nussbaum RM (1988) The effect of low concentration fire retardant impregnations on wood charring rate and char yield. Journal of Fire Sciences 6:290-307

Ostman BAL, Mikkola E (1996) European fire tests for floorings. Interflam 1999:819

Ostman BAL, Mikkola E (2006) European classes for the reaction to fire performance of wood products. Holz als Roh- und Werkstoff 64:327-337 
Pabelina KG, Lumban CO, Ramos HJ (2012) Plasma impregnation of wood with fire retardants. Nuclear Instruments and Methods in Physics Research B 272:365-369

Parker WJ (1992) Heat release in fires. In: Babrauskas V, Grayson SJ (eds) Wood Materials - prediction of the heat release from basic measurements. Elsevier Applied Sciences, New York

Pereyra AM, Giudice CA (2008) Ethyl silicates with different hydrolysis degree like non-flammable impregnating material for wood. Ciencia y Tecnologia 10:113-127

Pereyra AM, Giudice CA, Benitez JC (2009) Fire retardant impregnants for woods based on alkaline silicates. Fire Safety Journal 44:497-503

Qu H, Hao J, Wu W, Zhao X, Jiang S (2012) Optimization of sol-gel coatings on the surface of ammonium polyphosphate and its application in epoxy resin. Journal of Fire Sciences 30:357-371

Quintiere JG (1997) Principles of Fire Behaviour. Delmar Publishers, New York, USA

Reszka P (2008) In-depth temperature profiles in pyrolzing wood. Dissertation. University of Edinburgh, Scotland

Rowell RM (1984) The Chemistry of Solid Wood. In: Advances in Chemistry Series. American Chemical Society, Washington

Rupper P, Gaan S, Salimova V, Heuberger M (2010) Characterization of chars obtained from cellulose treated with phosporamidate flame retardants. J Anal Appl Pyrolysis 87:93-98

Schartel B (2010) Phosphorus-based flame retardancy mechanisms - old hat or a starting point for future development. Materials 3:4710-4745

Schartel B, Hull TR (2007) Development of fire-retarded materials - interpretation of cone calorimeter data. Fire and Materials 31:327-354

Schwenker RF Jr, Pascu E (1958) Chemically modifying cellulose for flame resistance. Ind Eng Chem 50:91-96

Sertsova AA, Koroleva MY, Yurtov EV, Pravednikova OB (2010) Fire-resistant polymer nanocomposites based on metal oxides and hydroxides. Nanotechnologies and Nanaomaterials 44:772-777

Sjogren B, Iregren A, Jarnberg J (2010) Phosphate triesters with flame retardant properties. University of Gothenburg, Arbete och Halsa, pp 1-220

Slimak KM, Slimak RA (2004) Process of using sodium silicate to create fire retardant products. US Patent, US, 6,827,984 B2, 7 Dec 2004

Spearpoint MJ, Quintiere JG (2000) Predicting the burning of wood using an integral model. Combustion and Flame 123:308-325

Stevens R, Van Es DS, Bezemer R, Kranenbarg A (2006) The structure-activity relationship of fire retardant phosphorus compounds in wood. Polymer Degradation and Stability 91:832-841

Sweet S, LeVan SL, White RH, Tran HC, DeGroot R (1996) Fire performance of wood treated with combined fire-retardant and preservative Systems: FPL-RP -545. Forest Products Laboratory, Madison, WI

Tomann J (1993) Comparison of Nordtest FIRE 007, CEN Draft Proposal (radiant Panel) and Cone calorimeter methods in the fire testing of floor coverings. Fire and Materials 17:189-190

Tran HC (1992) Heat release in fires: experimental data on wood materials. In: Babrauskas V, Grayson SK (eds) Heat Release in Fires. Elsevier Applied Science, New York

Van der Veen I, De Boer J (2012) Phosphorus flame retardants: Properties, production, environmental occurrence, toxicity and analysis. Chemosphere 88:1119-1153

Wang Q, Li J, Winandy JE (2004) Chemical mechanism of fire retardance of boric acid on wood. Wood Science Technology 38:375-389

White RH (2000) Fire performance of hardwood species. Paper presented at the XXI IUFRO World Congress, Kuala Lumpur, Malaysia

White RH, Dietenberger M (2001) Wood Products: Thermal Degradation and Fire. Encyclopedia of Materials, Science and Technology, pp 9712-9716

Wiedenhoeft AC, Miller RB (2005) Structure and Function of Wood. In: Rowell RM (ed) Handbook of wood chemistry and wood composites. CRC Press, Florida, pp 9-32

Wilkins E, Murray F (1980) Toxicity of emissions from combustion and pyrolysis of wood. Wood Science and Technology 14:281-288

Winandy JE (1995) Effects of fire retardant treatments after 18 months of exposure at $150^{\circ} \mathrm{C}\left(66^{\circ} \mathrm{C}\right)$ : res note FPL-RN-0264. USDA Forest Services, Madison, WI

Winandy JE, Herdman D (2003) Evaluation of boron-nitrogen, phosphate-free fireretardant: Part II. Evaluation of small, clear specimens according to Methods A and B of ASTM D5664-95. ASTM Journal of Testing and Evaluation 31:140-147

Winandy JE, McNamara W (2003) Evaluation of a boron-nitrogen, phosphate-free fire-retardant treatment: Part III. Evaluation of Full-Size 2 by 4 Lumber per
ASTM Standard D 5664-95 Method C. Journal of Testing and Evaluation 31:148-153

Winandy JE, Richards MJ (2003) Evaluation of boron-nitrogen, phosphate-free fire-retardant: Part I. Evaluation of Douglas-fir plywood according to ASTM D5516-96. ASTM Journal of Testing and Evaluation 31:133-139

Yang CQ, He Q (2012) Textile heat release properties measured by microscale combustion calorimetry: experimental repeatability. Fire and Materials 36:127-137

Yang L, Chen X, Zhou X, Fan W (2003) The pyrolysis and ignition of charring materials under an external heat flux. Combustion and Flame 133:407-413

Yang H, Yan R, Chen H, Zheng C, Lee D, Liang DT (2006) In-depth investigation of biomass pyrolysis based on three major components: hemicellulose, cellulose and lignin. Energy Fuels 20:388-393

Yang Z, Fei B, Wang X, Xin JH (2012) A novel halogen-free and formaldehydefree flame retardant for cotton fabrics. Fire and Materials 36:31-39

Zhu H, Zhu Q, Li J, Tao K, Xue L, Yan Q (2011) Synergistic effect between expandable graphite and ammonium polyphosphate on flame retarded polyactide. Polymer Degradation and Stability 96:183-189

doi:10.1186/2193-0414-2-4

Cite this article as: Lowden and Hull: Flammability behaviour of wood and a review of the methods for its reduction. Fire Science Reviews 2013 2:4.

\section{Submit your manuscript to a SpringerOpen ${ }^{\odot}$ journal and benefit from:}

- Convenient online submission

- Rigorous peer review

- Immediate publication on acceptance

- Open access: articles freely available online

- High visibility within the field

- Retaining the copyright to your article

Submit your next manuscript at $>$ springeropen.com 